\title{
The Analysis of Sentences' Structure of Students' Compositions at Grade VI of Elementary Schools in Bali Province
}

\author{
Ida Bagus Putrayasa, Dewa Putu Ramendra, Ida Bagus Putra Manik Aryana \\ Ganesha University of Education \\ ibputra@gmail.com
}

\begin{abstract}
In conveying their ideas in writing, students often found some difficulties in composing sentences. The sentences composed, are not clear in terms of the structures, so that the ideas conveyed could not be understood well. Based on this situation, the main purpose of this study was to describe sentence structure used in the composition of grade VI students in Bali Province. The data were collected through document recording method of 120 compositions, each consisting of 3 paragraphs. The collected data were analyzed through Burton-Roberts analysis model. The results showed that there are 1.035 sentences. The structures of sentences, both simple or compounds contained in the essay of grade VI students in Bali province were quite varied. Based on the results obtained, it was suggested to the students to keep on paying attention on sentence structure in writing essay for the effectiveness of the ideas delivered.
\end{abstract}

Keywords-syntactic analysis; unity; structure; essay

\section{INTRODUCTION}

In conveying ideas in writing, students often found some difficulties composing sentences. The sentences composed, were not clear in terms of the structures, so that the ideas conveyed could not be well understood. Therefore, a sentence became very important to be understood and mastered when conveying ideas, both orally and in writing. A sentence is a sequence of words that make sense (Reyner, 2016; Collins \& Stabler, 2016; Robert-Burton, 1997). Another opinion revealed that a sentence is a relation between single word with another. These interrelationships form an understanding (Putrayasa, 2014a; 2014b; 2014c). Meanwhile, another expert revealed that phrase is a string of words which carries a full idea (Collin \& Stabler, 2016, Osborne, et.al, 2012). In the string of the words, there are ideas submitted, which are represented at least through subject and predicate elements (Batterink \& Neville, 2013). The elements of a sentence have a harmony between the formers, the harmony of the subject with the predicate, the harmony of the predicate with the object, the harmony of the predicate with the adverbs (Robert-Burton, 1997; Putrayasa, 2014a). In addition to the harmony, another aspect to be considered in the sentence is the type of sentence used, the unity of the sentence, and the sentence structure used in delivering ideas (Clifton \& Frevier, 2010; Putrayasa, 2014b). The harmony of sentence elements, sentence unity, and sentence structure were what needs to be understood and mastered when communicating.

However, words strings were often discovered without full comprehension, both used in oral communication and written communication. One of these written communications was in a student's composition. A composition is a combination of several interconnected sentences, containing ideas. The composition was used only as a mean to analyze the sentences made by the students in their essay. In composing, students employed word strings to deliver their ideas, but there are some that did not contain a complete idea (understanding). This incomplete idea was shown by the nonpresence of Subject and Predicate. This was what made the students' composition interesting to be analyzed from the aspect of sentence unity and structure. These aspects could refine the syntactic study in the students' essay. In his research on syntax, especially sentence study, Putrayasa (2008) revealed that the students still had some difficulties to determine a word function in a sentence structure, whether as subject, predicate, object, complement, or adverb in a sentence.

There were several studies that discussed syntax, among others: Putrayasa $(2008,2010,2014)$, Maimunah (2014), and Baryadi (2014). The studies that had been conducted did not discuss in detail matters relating to sentence unity and sentence structure. Putrayasa's research (2008) which was conducted in Singaraja City only studied the subjects and predicates in students' essay through qualitative and quantitative approach. In 2010, a research on syntactic studies was conducted again, but only studied the mastery of students in distinguishing elements of objects and complements. Maimunah's study (2014) only examined clauses in terms of functions, categories, and roles in the Surah Al-Qari'ah's translation. The study had not been comprehensive, had not touched on sentence unity and structure in the Surah Al-Qari'ah's translation. Meanwhile, a research conducted by Baryadi (2014) only discussed the sequences of clauses in subordinative compound sentences in Indonesian language studied from a syntactic perspective.

A fairly comprehensive research related with the study of syntax, especially sentence elements but done separately, also conducted by Putrayasa (2014). His research examined the different elements of objects andadverbial. 
The results showed that students' ability was still low (average: 5.75) in determining the elements of the sentences. This was due to the poor students' understanding on the concept of sentences, the concept of the elements that form sentences in terms of type, unity, and structure. This poor understanding was added by the lack of exercises on how to determine sentence elements. With such poor understanding and practice, this would have an impact on the low quality of the language (sentences) used in conveying ideas, both orally and in writing.

Based on the above description of the background, the making of a study and theory about syntax, especially regarding sentence unity and structure, seemed urgent to do. This study had a strategic position as a basis for further research development and could be practically used as a reference of knowledge in delivering ideas orally or in writing. According to the description of the research and statements of earlier scholars and researchers, the mastery of syntax (especially sentences) could be understood in at least two aspects of the study: sentence unity and sentence structure. However, the problem that is focused in research ishow was the sentence structure in the essay of the sixth grade students of elementary school in Bali province?

\section{METHODS}

The design used in this research was descriptive qualitative design. The source of research data was the essays of grade VI students in the province of Bali. The sample determination used random area sampling technique, namely random to elementary school representing North Bali, South Bali, West Bali, and East Bali. Each of these areas was represented by Buleleng Regency representing North Bali, Tabanan representing South Bali, Jembrana representing West Bali, and Karangasem representing East Bali. From each district was be taken 3 elementary schools, each with good category, medium, and less. Of each elementary school was taken 10 students'essays. Thus, a total of 12 elementary schools and 120 student essays were used as samples of year I as shown in the table below.

Table 1. School Samples and Students' Essays

\begin{tabular}{clcc}
\hline No. & \multicolumn{1}{c}{ District } & $\begin{array}{c}\text { The Number of } \\
\text { Elementary } \\
\text { Schools }\end{array}$ & $\begin{array}{c}\text { The Number of } \\
\text { Students'Essays }\end{array}$ \\
\hline 1 & Buleleng & 3 & 10 \\
\hline 2 & Tabanan & 3 & 10 \\
\hline 3 & Jembrana & 3 & 10 \\
\hline 4 & Karangasem & 3 & 10 \\
\hline \multicolumn{2}{r}{ Total } & 12 & 120 \\
\hline
\end{tabular}

The method used in collecting data was document recording method. The collected data were analyzed through Robert-Burton analysis model.

\section{FINDING AND DISCUSSION}

The data studied came from the essays of grade VI students in Bali province. The total number of essays was 120, each of which consisted of 3 paragraphs. The total number of sentences was 1,035 . This whole sentence was examined from the aspect of sentence unity and structure, as shown in the description below.

\section{Sentence Structure in the Essays of Grade VI elementary School Student in Bali Province}

Based on data analysis conducted, it was discovered the following sentence structure in the essay of grade VI elementary school students as shown in Table 2 below. 
Table 2. The Sentence Structure in the Essays of Grade VI Elementary School Student in Bali Province

\begin{tabular}{|c|c|c|c|}
\hline No. & Simple & Sentence Structure & Compound \\
\hline 1 & $\mathrm{~S}-\mathrm{P}$ & S-S-P & \\
\hline 2 & $\mathrm{~S}-\mathrm{P}-\mathrm{O}$ & S-S-P-O & \\
\hline 3 & $\mathrm{~S}-\mathrm{P}-\mathrm{K}$ & S-S-P-Pel & \\
\hline 4 & $\mathrm{~S}-\mathrm{P}-\mathrm{K}-\mathrm{K}$ & S-P-P & \\
\hline 5 & $\mathrm{~S}-\mathrm{P}-\mathrm{Pel}$ & S-P / S-P & \\
\hline 6 & $\mathrm{~S}-\mathrm{P}-\mathrm{O}-\mathrm{K}$ & S-S-P-O / P-O & \\
\hline 7 & $\mathrm{~S}-\mathrm{P}-\mathrm{Pel}-\mathrm{K}$ & S-S-P-K & \\
\hline 8 & $\mathrm{~S}-\mathrm{K}-\mathrm{P}-\mathrm{O}$ & S-S-P-O-K & \\
\hline 9 & $\mathrm{~S}-\mathrm{K}-\mathrm{P}-\mathrm{Pel}$ & S-P-P-K & \\
\hline 10 & $\mathrm{~S}-\mathrm{O}-\mathrm{P}-\mathrm{K}$ & S-P-O / P-Pel & \\
\hline 11 & $\mathrm{P}-\mathrm{S}$ & S-P-O-K / S-P-O-K & \\
\hline 12 & $\mathrm{P}-\mathrm{S}-\mathrm{K}$ & S-P-O / S-P / S-P-K / S-P & \\
\hline 13 & $\mathrm{~K}-\mathrm{S}-\mathrm{P}$ & S-P-P-P-O-K & \\
\hline 14 & $\mathrm{~K}-\mathrm{P}-\mathrm{S}$ & $\begin{array}{l}\text { S-P-O / S-P / K-S-P-K / K-S-P / } \\
\text { S-P }\end{array}$ & \\
\hline 15 & $\mathrm{~K}-\mathrm{S}-\mathrm{P}-\mathrm{O}$ & $\begin{array}{l}\text { S-P-O / S-P-O / S-P-K / S-P-K / } \\
\text { S-P / S-P-K }\end{array}$ & \\
\hline 16 & $\mathrm{~K}-\mathrm{S}-\mathrm{P}-\mathrm{Pel}$ & $\begin{array}{l}\text { S-P-Pel / S-P-K / S-P-Opel / S- } \\
\text { P-O / S-P-K }\end{array}$ & \\
\hline 17 & $\mathrm{~K}-\mathrm{S}-\mathrm{P}-\mathrm{K}$ & $\mathrm{P}-\mathrm{S} / \mathrm{P}-\mathrm{S}$ & \\
\hline 18 & $\mathrm{~K}-\mathrm{K}-\mathrm{S}-\mathrm{P}$ & P-S / S-P-O-K-K & \\
\hline 19 & & P-S / S-P-P & \\
\hline 20 & & P-S-K / S-P-K & \\
\hline 21 & & P-S / S-P-Pel / P-S & \\
\hline 22 & & P-P-P-S-K & \\
\hline 23 & & P-O-S-P & \\
\hline 24 & & P-K-S-P-K & \\
\hline 25 & & P-K-S-P-K / S-P & \\
\hline 26 & & P-S / S-P / P-S / P-S-Pel & \\
\hline 27 & & K-S-P-P & \\
\hline 28 & & K-S-S-P-K & \\
\hline 29 & & K-S-P-P-O & \\
\hline 30 & & K-S-P / S-P & \\
\hline 31 & & K-S-P-O / P-O & \\
\hline 32 & & K-S-P-O / K-S-P-P-K & \\
\hline 33 & & K-S-P-K / S-P-Pel-K & \\
\hline 34 & & K-S-P-O / P-K /S-P-O /S-P-K & \\
\hline 35 & & K-P-S / P-S-K / S-P / S-P-P & \\
\hline 36 & & $\begin{array}{l}\text { P-S-K / K-S-S-P-P-K / K-S-P-O } \\
\text { / K-S-P / } \\
\text { K-S-P / K-S-P / K-S-P / K-S-P / } \\
\text { K-S-P-O / }\end{array}$ & \\
\hline 37 & & $\begin{array}{l}\text { S-P-Pel } \\
\text { K-S-P-O-K / S-P-O / S-P / S-P- } \\
\text { O / S-P / S-P / } \\
\text { / S-P / S-P / S-P / S-P / S-P / S-P } \\
\text { / S-P / } \\
\text { S-P-K / S-P }\end{array}$ & \\
\hline
\end{tabular}

The table above shows that the sentence structure contained in the essays of sixth grade elementary school students in Bali Province is quite varied, both in single sentences and compound sentences. The variability of this single sentence structure is reflected in the sentences used to express ideas through their essays. The single sentence used to 
pour the idea is a general structure, ie Subject (S) precedes Predicate (P) (Nordquist, 2016). This general structure is seen in numbers (1) through (10). The general sentence structure or ordinary sentence structure is a sentence structure that is the same as the predicate (Thornoboy, 2009; Vallin, \& LaPolla, 1997; Putrayasa, 2017). In addition to the general structure, there is also a single sentence with a structure of inversion or reverse arrangement, ie the core $\mathrm{P}$ precedes the core S (Putrayasa, 2014a; Tallerman, 2011), as shown in numbers (11) and (12), or parts of P precede S, as shown in the single sentence number (13) to number (18).

Besides the single sentence structure used to express ideas in essays, students also use compound sentence structures. Compound sentences are sentences consisting of two or more clauses (Reyner, 2016; Putrayasa, 2011). Usually, in terms of structure, compound sentences are characterized by the presence of two elements $\mathrm{S}$ and one element P, or one element S and two elements P (Putrayasa, 2014a).

Similar to a single sentence structure, in compound sentence structures also found common or ordinary compound sentence structures and inversion structures. A common compound sentence structure, whose subject precedes predicate (Putrayasa, 2017) is found in the number structure (1) up to number (16). Meanwhile, the compound sentence structure is inversion or reversed with the core $\mathrm{P}$ preceding $\mathrm{S}$ is in the number structure (17) up to number (26). For inversion structures the elements of parts of $P$ precede $S$ are in the number structure (27) up to number (37).

The variability of sentence structure used by students shows that the level of intellectual maturity and level of language ability is quite high. This is in accordance with the views of Winch, G., at.al. (2006) which states that the higher the level of one's intellectual maturity, the higher the level of language ability. This means that the high level of language ability of a person will also affect the high variation of sentence structure used in conveying ideas.

\section{CONCLUSION}

Based on the results and data analysis above, it could be concluded as follows. The sentence structures in the essay of grade VI of elementary school students in Bali Province were simple and compound sentence structures, which were quite varied. Based on these conclusions, it could be recommended that the sentence structure in conveying ideas should be maintained so that communication, both orally and in writing, became effective.

\section{References}

Baryadi, P. (2014). Urutan klausa dalam kalimat majemuk subordinat bahasa Indonesia: kajian dari perspektif sintaksis dan wacana. Jurnal Sintaksis Lanjut, Rabu 4 Juni 2014.

Batterink, L. \& Neville, H.J. (2013). The human brain processes syntax in the absence of concious awareness. The Journal of Neuroscien, 8 May 2013, 33 (19): 8528-8533; doi:10, 1523/J/NEUROSCI.0618-13. 2013.

Bogdan, R.C. \& Biklen, S.K. (1990). Penelitian Kualitatif untuk Pendidikan. Jakarta: Pusat Antar Universitas.

Chomsky, N. (1985). Syntactic structures. Paris: Mouton Publishers.

Clifton, C. \& Frazier, L. (2010). Imperfect ellipsis: antecedents beyond syntax? Journal of Syntax.Vol.13, Issue 4, p 279-297, Des. 2010. Blackwell Publising LTd.

Collin, C. \& Stabler, E. (2016). A formalization of minimalist syntax. Journal of Syntax. Vol.19, Issue 1, p 43-78, March 2016. Blackwell Publising LTd.

Huddleston, R.D. \& Uren, O. (1981). Declarative, interogative, and imperative in French dalam M.A.K. Halliday dan J.R. Martin (Ed.). Reading in systemic linguistics: 237-256. London: Batsford Academic and Education Ltd.

Lincoln, Y.S. \& Guba, E.G. 1985.Naturalistic inquiry. New Delhi: Sage Publication.

Lindlof, T. R. (1994). Qualitative communication research methods. Thousand Oaks: SAGE Publiser.

Maimunah, S. (2014). Analisis klausa berdasarkan fungsi, kategori, dan peran pada terjemahan Surah Al-Qaria'ah Ayat 1-11. Jurnal Sintaksis Lanjut, Rabu 4 Juni 2014.

Nordquist, R. (2016). Grammar basics: sentences parts and sentences structure. http://grammar.about.com/od/rs/fl/sentence-structure.htm.

Osborne, T. at.al. (2012). Catenae: introducing a novel unit of syntactic analysis. Journal of Syntax.Vol.15, Issue4, p 354-396, Des. 2012. Blackwell Publising LTd.

Putrayasa, I.B. (2001). Penerapan model inkuiri dalam pembelajaran bahasa Indonesia (unsur-unsur kalimat tunggal). Disertasi (Tidak diterbitkan).

Putrayasa, I.B. (2002). Penerapan model inkuiri dalam pembelajaran bahasa Indonesia. Jurnal Pendidikan dan Pengajaran, No.2 Tahun XXXV April 2002.

Putrayasa, I.B. (2008). Tata kalimat. Aksara, Jurnal Bahasa dan Sastra, No.32, Tahun XIX. Desember 2008. Balai Bahasa Denpasar.

Putrayasa, I.B. (2010). Penerapan model konstruktivisme berpendekatan inkuiri dalam pembelajaran bahasa Indonesia (Studi penelusuran miskonsepsi dalam pembelajaran kalimat). Jurnal Pendidikan dan Pengajaran Undiksha, Jilid 43, No.1, April 2010. 
Putrayasa, I.B. (2011). Studi penelusuran miskonsepsi dalam pembelajaran sintaksis (tata kalimat) dengan model konstruktivisme berpendekatan inkuiri pada siswa kelas I SMPN di kota Singaraja, kabupaten buleleng, provinsi Bali. (Prosiding Konferensi Internasional Masyarakat Linguistik Indonesia -KIMLI-, 2011).

Putrayasa, I.B. (2012). Jenis kalimat dalam bahasa Indonesia. Bandung: Refika Aditama.

Putrayasa, I.B. (2013). Penelusuran miskonsepsi dalam pembelajaran tata kalimat (unsur objek dan pelengkap) dengan pendekatan konstruktivisme berbasis inkuiri. Jurnal Pendidikan Indonesia Volume 2, Nomor 2, Oktober 2013

Putrayasa, I.B. (2014a). Tata kalimat bahasa Indonesia. Bandung: Refika Aditama.

Putrayasa, I.B. (2014b). Analisis kalimat (fungsi, kategori, dan peran). Bandung: Refika Aditama.

Putrayasa, I.B. (2014c). Kalimat Efektif (Diksi, Struktur, dan Logika). Bandung: Refika Aditama.

Putrayasa, I.B. (2015). Pembelajaran bahasa Indonesia (kalimat: unsur objek dan adverbial) dengan model konstruktivisme berpendekatan inkuiri. (Prosiding Seminar Internasional, Malang, 28-29 September 2015).

Putrayasa, I.B. (2016). Kajian pengajaran bahasa dan sastra Indonesia. Makalah Disampaikan dalam Seminar Nasional Bahasa, Sastra, dan Pengajarannya IV. Denpasar, 2016.

Putrayasa, I.B. (2017). Sintaksis (memahami kalimat tunggal). Bandung: Refika Aditama.

Putrayasa, I.B. (2017). Penggunaan kalimat pada jurnal ilmiah pendidikan dan pembelajaran program pascasarjana. (Laporan Penelitian). Singaraja: Universitas Pendidikan Ganesha.

Putrayasa, I.B. (2017a). The semantic study of language politics. International Journal of Linguistics, Language, and Culture (IJLLC). 3 (2), March 2017, p.6-11 ISSN: 2455-8028, Imfact Factor: 4.665/Thomson Reuters: K-42882016.

Putrayasa, I.B. (2017b). Unity and effectiveness of the abstract language beginner lecturer research institution (Undiksha) 2015. IOSR Journal of Humanities and Social Science (IOSR-JHSS). 22 (3), Ver.V (March 2017), p.23-28, e-ISSN: 2279-0837, p-ISSN: 2279-0845

Reyner, K. (2016). The interaction of syntax and semantic during sentence proccessing: eye movements in the analysis of semantically based sentences. Departement of Psychology University of Massachussetts, Mass.01003.Published by Elsevier Inc.

Robert-Burton, N. (1997). Analysing sentences. New York: Longman.

Tallerman, M. (2011). Understanding syntax. London: Hodder Education.

Thornoboy, S. (2009). How to teach grammar. Edinburgh: Pearson Education Limited.

Vallin, R.D.V. \& LaPolla, R.J. (1997). Syntax: structure, meaning, and fungtion. Cambridge: University Press.

Winch, G. at.al. (2006). Literacy: reading, writing, and children's literature. 3rd ed. New York: Oxford. 